\title{
Timing and origin of early Mesozoic granitoids in the Qinling orogen, central China and implications for orogenic processes
}

\author{
XiaOXIA Wang ${ }^{1}$, TAO WANG ${ }^{2,3}$, ChanghUI KE ${ }^{1}$, YANG \\ YANG $^{4}$, YONG FEI TIAN ${ }^{1}$ \\ ${ }^{1}$ MLR Key Laboratory of Metallogeny and Mineral \\ Assessment, Institute of Mineral Resources, CAGS, \\ Beijing 100037, China \\ ${ }^{2}$ Beijing SHRIMP Center, Beijing 100037, China \\ ${ }^{3}$ Institute of Geology, CAGS, Beijing 100037, China \\ ${ }^{4}$ Chang'an University, Xi'an 710054, China
}

The Qinling orogen (QO), one of the most important orogens in Asia, was finally formed by suturing of the Mianlue ocean (a branch of Paleo-Tethyan ocean) and the collision of the North China block (NCB) and South China block (SCB) during early Mesozoic. Early Mesozoic granitoids are widespread in the QO but their origin and significance are not well understood. In this study, we present new data of zircon $\mathrm{U}-\mathrm{Pb}$ ages, whole-rock and $\mathrm{Nd}-\mathrm{Hf}$ isotopic compositions, combined with data from literature, to study the timing, origin and evolution of these granitoids and their implications for the orogenic processes. 181 zircon $\mathrm{U}-\mathrm{Pb}$ ages show three magmatic phases $(252-230 \mathrm{Ma}, 230-210 \mathrm{Ma}$ and 210-185 Ma). The first phase consists mainly of diorite and granodiorite. The second and third phases are composed of monzogranite, some adakitic rock and occasionally rapakivitextured granitoid. From the first to third phase, the granitoid magmatism evolved from calc-alkaline and high-K calcalkaline I-type to high-K calc-alkaline and shoshonite I- and I-A types, characterized by higher $\mathrm{SiO}_{2}$ and $\mathrm{K}_{2} \mathrm{O}+\mathrm{Na}_{2} \mathrm{O}$ and more obvious negative anomaly of Eu and depletion in $\mathrm{Nd}, \mathrm{Sr}$, $\mathrm{P}$ and Ti. The magmatic evolution suggests that the firstphase granitoid was related to the subduction of the Mianlue ocean, and the second- and third-phase granitoids to syn- and post-collision of the NCB and SCB, respectively. Besides, the second- and third-phase granitoids, especially the secondphase, have larger variation in geochemistry, lower $\varepsilon_{\mathrm{Nd}}(t)$ and $\varepsilon_{\mathrm{Nd}}(\mathrm{t})$ values and older $\mathrm{T}_{\mathrm{DM} 2(\mathrm{Nd})}$ and $\mathrm{T}_{\mathrm{DM} 2(\mathrm{Hf})}$ than those of the first-phase. These suggest that more ancient continental compositions had been involved in the second- and thirdphase magmatism. It confirms the transition from subduction to syn-collision, and then to post-collision. This study also demonstrates that the orogenic processes was strongly involved by old continental compositions and characterized by collisional signature. It contrasts with typical accretionary orogens such as the Central Asian Orogenic Belt. 